\title{
The Ideal of Female Beauty in Greek Tombstone Inscriptions and Writings of Early Christian Authors. Some Remarks and Examples.
}

\author{
ANDREA KOREČKOVÁ \\ Reformed Christian Church, Slovakia \\ e-mail: andrea.koreckova@gmail.com \\ ORCID: 0000-0003-1103-9675
}

\begin{abstract}
The extant remains from both Classical and Hellenistic periods portray a body of a Greek woman in all its beauty. They do not cover what was once revealed. On the contrary, they bring the female beauty to the centre of attention. This freedom of expression gradually disappears and a body is exposed only when portraying a woman with colourful past to show her failures. This paper introduces Greek tombstone inscriptions that captured female beauty for the future generations. Upon this, a question arises: what do these inscriptions mean to a casual reader? What is their purpose? What value did a beautiful woman have in the ancient society? Was she somewhat different from those around her? How did emerging Christianity react to the Greek ideal of beauty? What ideas were adopted and what ideas were firmly rejected? These and many other questions have arisen during the study of the inscriptions that engage people even today.
\end{abstract}

KEYwORDs: tombstone inscriptions, female beauty, antiquity, Christian authors

Eemale beauty - a virtue or a sin? It seems that the perception of female beauty F is a matter of perspective that reflects the beliefs of a particular historical period. It is interesting to observe how the reasons for emphasising or concealing female beauty have changed over time. The extant remains from both Classical and Hellenistic periods portray a body of a Greek woman in all its beauty. They do not cover what was once revealed. On the contrary, they bring the female beauty to the centre of attention. This freedom of expression gradually disappeared and a body is exposed only when portraying a woman with colourful past with the purpose of showing her failures. This shift can also be observed in Greek tombstone inscriptions that captured female beauty for the future generations.

For the purpose of our research, presented in this paper, we limited ourselves to the tombstone inscriptions dated to $300 \mathrm{BC}-200 \mathrm{AD}$ because they reflect the Hellenistic period, early empire, the intertestamental period and also the period of early Christianity (in some instances we also referred to the inscriptions dated 
to the $3^{\text {rd }}$ and $4^{\text {th }}$ cent. AD, but only to complement the study; there was no shift in thinking detected in those inscriptions).

Another criterion taken into consideration in our research was a language in which the tombstone inscriptions were written - the Greek language with all that is associated with it: the Greek culture, mythology, religiosity, and cult that were all known throughout the world at that time (e.g. Greece, Asia Minor, Egypt, and Italy). Common attitudes influenced by a single language can be found in various locations. Therefore, we left aside other criteria such as categorizing the inscriptions according to individual locations, centuries, well-known authors, or local stonemasons; classification of inscriptions into those that were unique or those that were passed on in families and tailored to the needs of specific person, etc. This creates a room for other researchers who are welcomed to apply different criteria to their own research.

Upon this, a few questions arise: what do these inscriptions mean to a casual reader? What is their purpose? What value did a beautiful woman have in the ancient society? Was she somewhat different from those around her? How did emerging Christianity react to the Greek ideal of beauty? What ideas were adopted and what ideas were firmly rejected? These and many other questions have arisen during the study of the inscriptions and engage people even today.

\section{Greek tombstone inscriptions (c. $350 \mathrm{BC}-300 \mathrm{AD}$ )}

\subsection{A contact with divinity}

In a way, a tombstone inscription is a summary of one's life, inviting a passerby to approach it in a similar manner. Although some inscriptions are very generic, some are rather daring. Especially those that liken the deceased women to deities based on their qualities, deeds, thinking styles, appearance, or their life stories. They reveal that gods endowed the deceased women with good fortunes for their exceptional attitudes they had adopted during their lifetime. Here are some examples that even a new generation of readers might find inspirational.

Plautia from Cyrene ( $2^{\text {nd }} / 1^{\text {st }}$ cent.) was described as "the one who resembles gods" $\left(\theta \in \tilde{n} s \text { i } \kappa^{\prime} \lambda \eta \nu\right)^{1}$ most likely because ${ }^{2}$ :

GG n ${ }^{\circ} 132 ; \mathrm{GV}^{\circ} 758$.

2 Greek tombstone inscriptions portray male beauty too. Just as it was true for women, male beauty was often coupled with another exceptional quality the deceased possessed. The inscription from Nea Isaura, Isaurien $\left(3^{\text {rd }} / 4^{\text {th }}\right.$ cent.) reveals a story of Hylas whose size and strength resembled

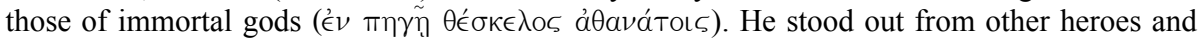

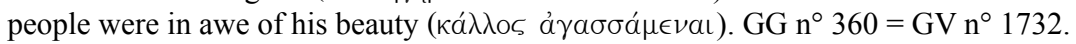


a) she liked weaving, the craft she possibly "took over" from Athena, a goddess associated with art and handicraft ${ }^{3}$.

b) she was a mother, a wife and a keeper of the home. This is yet another reference to reverence towards the gods (Aristotle, De partibus animalium, 1,5$)^{4}$.

A similar inscription praising female beauty is of Egyptian provenance $\left(2^{\text {nd }} / 3^{\text {rd }} \text { cent. }\right)^{5}$ and reads that Kyrilla resembles gods $i$ her appearance

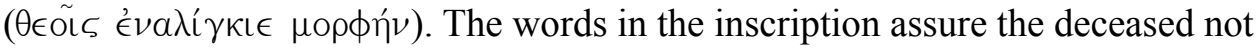
to lose her heart for she is resting in the realm of no death ( $\left.\chi \tilde{\omega} \rho \rho_{\nu} \dot{a} \theta \alpha \nu \alpha \dot{\tau} \omega \nu\right)$. Her beauty remains; it does not wither away unlike the beauty of those in the underworld ${ }^{6}$. Kyrilla's beauty is preserved for eternity.

This inscription does not give us a clear implication as to what personality trait appealed to people around her. It might have been her figure, her beauty, her charm, or the overall feeling her personality radiated ${ }^{7}$.

The Egyptians placed a very high emphasis on their physical appearance. The physical beauty was something to strive for. The desire to closely resemble the Egyptian gods was very strong. The more impeccable appearance, the more authentic reflection of divine perfection. The main criterion of beauty in ancient Egypt was eternal youth: face with no wrinkles, no grey hair, smooth complexion, full head of hair, a long neck, a slender figure, intense scent, perfect teeth, etc. ${ }^{8}$. Lavishly adorned reliefs on sarcophagi also depict many of these ideas.

In ancient Greece, likeness with gods was perceived as attainment of the highest level of excellence (å $\rho \in T \eta \dot{)}$ ) through one's beauty, intelligence, strength and a constant development of virtues one needs in order to achieve immortality ${ }^{10}$.

Many tombstone inscriptions remind the passersby that the deceased women were young and beautiful. Youth was associated with the Olympian deities ${ }^{11}$.

\footnotetext{
V. Zamarovský, Bohovia a hrdinovia antických báji (Bratislava: Perfekt 1998) 75.

J. P. Vernant (ed)., Řecký člověk a jeho svět (Praha: Vyšehrad 2005) 223-230.

GG n $263=\mathrm{GV} \mathrm{n}^{\circ} 1411$; J. G. Milne, Greek Inscriptions (Oxford: Printed at the University Press by Horace Hart 1905) 76, 3304.

6 The bereaved of Theodora from Puteoli ( $3^{\text {rd }} / 2^{\text {nd }}$ cent. BC) say that: instead of getting married she descended to the underworld which destroys her beauty. $\mathrm{GG} \mathrm{n}^{\circ} 148=\mathrm{GV} \mathrm{n}^{\circ} 868$.

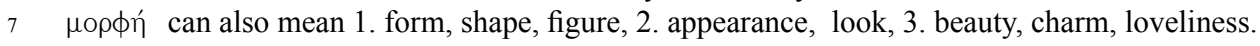
See more in H. Panczová, Grécko-slovenský slovník od Homéra po krestanských autorov (Bratislava: Lingea 2012) 838.

$8 \quad$ L. Green, "Beauty", The Oxford Encyclopedia of Ancient Egypt (ed. D. B. Redford) (Oxford: Oxford University Press 2001) I, 167-170.

9 An interesting collection can be found in D. Arnold, The Royal Women of Amarna: Images of Beauty from Ancient Egypt (New York: Metropolitan Museum of Art 1996).

10 Vernant, Řecký člověk, 230.

11 V. Bahník, Slovnik antické kultury (Praha: Nakladatelství Svoboda 1974) 37.
} 
Young and beautiful was also Modesta from Synnada, Phrygien ( $1^{\text {st }}$ cent. AD) ${ }^{12}$ or Nikaia from Antiochia, Syria $\left(1^{\text {st }} \text { cent. AD }\right)^{13}$.

Praxilla, an older woman from Phillippopolis ( $2^{\text {nd }}$ cent. AD), encountered the divine world, too. She was a mother of many children and had many grandchil-

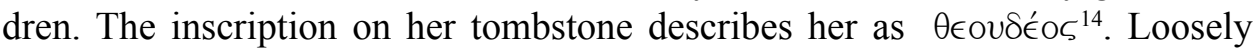
translated; it means a woman who revered gods. Perhaps that was a reason for her having many offspring. Each of them stood out among other people or distinguished themselves by the good deeds $\left(\dot{a} \rho\llcorner\sigma \tau \epsilon \hat{v} \omega)^{15}\right.$. By doing so; they neared perfection ${ }^{16}$ and deserved certain respect from both mortals and gods ${ }^{17}$.

\subsection{Female kalokagathia?}

Beauty and goodness or the physical beauty coupled with spiritual nobility was central to Greek education ${ }^{18}$ and was often depicted in the tombstone inscriptions of women. Here are some examples: Tyro, a daughter of Sosamenos of Crete (second half of the $2^{\text {nd }}$ cent. BC) was one of those who excelled in beau-

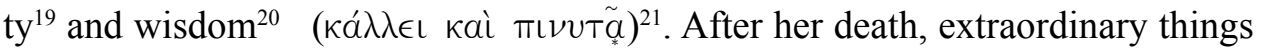
happened:

a) Virtue, portrayed here as a divinebeing 'A $A \in T a ́$, had her hair shorn in grief for the deceased since no one among the living could equal her in the way of life and thinking ${ }^{22}$.

$12 \mathrm{GG} \mathrm{n}^{\circ} 332=\mathrm{GV} \mathrm{n}^{\circ} 1554$; IGLSyr III, ${ }^{\circ} 915$ u. 685 .

$13 \mathrm{GG} \mathrm{n}^{\circ} 332=\mathrm{GV} \mathrm{n}^{\circ} 1554$; IGLSyr III n ${ }^{\circ} 915$ u. 685.

$14 \mathrm{GG} \mathrm{n}^{\circ} 236=\mathrm{GV} \mathrm{n}^{\circ} 92$.

15 This word has several meanings all of which praise the deeds of the concerned person over others: 1. be very good, excel: in battle, someone at, excel oneself, become famous, win, 2. be deserving, get reward, gain value (for one's heroism). Panczová, Grécko-slovenský slovník, 227.

16 Vernant, Řecký člověk, 230.

17 M. Mayordomo, „Möglichkeiten und Grenzen einer neutestamentlich orientierten Tugendethik”, ThZ 64 (2008) 220-233; I. Peres, Griechische Grabinschriften und neutestamentliche Eschatologie (WUNT 157; Tübingen: Mohr Siebeck 2003) 87, 166, 207, 221.

18 Bahník, Slovník antické kultury, 306.

19 The word кá $\lambda \lambda$ os has several meanings. 1. beauty, loveliness, splendour. It also means 2. makeup, which could be a reference to taking care of one's appearance or a praise for one's visage. Other meanings refer to some personality traits: 3. decency, 4. nobility. Panczová, Gréckoslovenský slovnik, 664.

$20 \pi$ TLvTós can also be translated as prudent, smart, clever, wise. Panczová, Grécko-slovenský slovnik, 1000.

$21 \quad \mathrm{GG} \mathrm{n}^{\circ} 149$.

22 Grieving Virtue with her hair cut at the grave of Aias can be also found in writings of Asclepiades (Anthol. Palat. VII $n^{\circ} 145$ ), Antipater of Sidon (Anthol. Palat. VII $\left.n^{\circ} 146\right)$ and Aulus Licinius Archias (Anthol. Palat. VII n ${ }^{\circ}$ 147). 
b) The entire Crete mourns her loss for Hades had stolen the best woman of all.

c) Even the sun will no more enjoy looks of a beautiful woman.

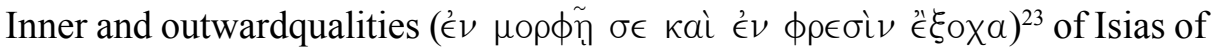
Mykonos ( $2^{\text {nd }} / 1^{\text {st }}$ cent. BC $)^{24}$ made her stand out among other women, which naturally pleased her husband. What is rather unusual about this inscription is the line referring to Hades appropriating the beauty of the deceased. What defined her personality seems to last ${ }^{25}$. The virtues at their best are depicted in the tombstone inscription from Rome ( $1^{\text {st }} / 2^{\text {nd }}$ cent.) capturing the life of Messia ${ }^{26}$. Despite

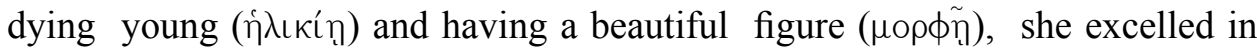
intellectual qualities, particularly in thinking $(\phi \rho \in \sigma i)$ and soundness of mind

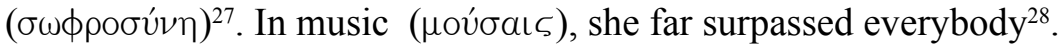

The external beauty as one of the glorified virtues does not always outlive the deceased woman. The tombstone inscription from Sardis $\left(2^{\text {nd }} / 1^{\text {st }}\right.$ cent. BC) supports this claim. It engaged a passerby in a way so that the deceased woman's personality traits, zeal, and conduct remained in the memory of the future generations $^{29}$. Menophila was such a prominent figure in this respect. She was an educated woman, a high office holder, and a virtuous housewife who was also described as nice $(\chi \alpha \rho i \epsilon \sigma \sigma \alpha)^{30}$.

23 Outer attributes ( $\mu о \rho \phi \eta ́)$ can refer to: 1. form, shape, figure, 2. appearance, look, 3. beauty, charm, loveliness. Panczová, Grécko-slovenský slovník, 838. qualities ( $\phi \rho \eta ́ v)$ arelinked to mental faculties, such as heart (=emotions, passions), spirit, mind, reason, thought, wit, purpose, memory, soul, senses. Panczová, Grécko-slovenský slovník, 1284.

$24 \quad \mathrm{GG} \mathrm{n}^{\circ} 205=\mathrm{GV} \mathrm{n}^{\circ} 1681$.

25 Similar conviction can be found in other sources: the prophecies of Hystaspes $\left(2^{\text {nd }}\right.$ cent. BC) quoted in Lactantius, Divinae Institutiones 7,21.3-6 ( $4^{\text {th }}$ cent. AD.), in The Testament of Abraham $13\left(1^{\text {st }}-3^{\text {rd }}\right.$ cent. AD), also in the Letter of Paul to the Corinthians 3:13-15.

26 GG n ${ }^{\circ} 396=\mathrm{GV} \mathrm{n}^{\circ} 1478$; Kaibel nº 682; IG XIV n ${ }^{\circ} 1853$.

27 The notion of $\sigma \omega \phi \rho \circ \sigma u ́ v \eta$ has several meaning: 1. prudence, deliberation, soundness of mind, judiciousness, saneness, 2. moderation (in pleasures and passions), modesty, temperance, frugality, self-control, composure, balance, 3. chastity, propriety, virtuousness, honesty. See Panczová, Grécko-slovenský slovnik, 1181 for more detailed explanation. For its multiple meanings this word often appears in the tombstone inscriptions, e.g.: $\mathrm{GG} \mathrm{n}^{\circ} 185=\mathrm{GV} \mathrm{n}^{\circ} 1392$; $\mathrm{GG} \mathrm{n}^{\circ} 281=\mathrm{GV} \mathrm{n}^{\circ}$ 668; $\mathrm{GG} \mathrm{n}^{\circ} 321=\mathrm{GV} \mathrm{n}^{\circ}$ 1294; $\mathrm{GG} \mathrm{n}^{\circ} 347=\mathrm{GV} \mathrm{n}^{\circ}$ 1678; Kaibel $\mathrm{n}^{\circ}$ 562; IG XIV n ${ }^{\circ} 2123$; $\mathrm{GG} \mathrm{n}^{\circ} 359=\mathrm{GV} \mathrm{n}^{\circ}$ 1736; Kaibel n ${ }^{\circ}$ 558; IG XIV n ${ }^{\circ}$ 2064; etc.

28 The tombstone inscription from $1^{\text {st }} \mathrm{c}$. AD (An d. Strasse v. Neapel $\mathrm{n}$. Nola) is written in similar style and praises the life of Kleopatra. The Olympian goddesses bestowed several virtues upon

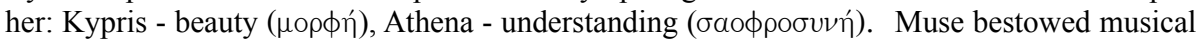

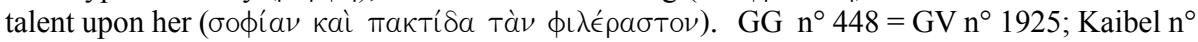
560; Geffcken $n^{\circ} 363$; IG XIV n 793.

$29 \quad \mathrm{GG} \mathrm{n}^{\circ} 433=\mathrm{GV} \mathrm{n}^{\circ} 1881$.

30 This adjective can also refer to someone: 1 . nice, pleasant, 2. charming, cute, pretty, comely, 3 . refined, smart, graceful, noble, witty. Panczová, Grécko-slovenský slovník, 1296. 
Similarly, Asclepiodote (Athens, $3^{\text {rd }} / 4^{\text {th }}$ cent.) is praised for the beauty of her immortal soul and the love she bore for her husband. She watches over him from heaven $^{31}$.

\subsection{On the way to Mount Olympus}

The beauty and wisdom of women fascinate the living. The question is what happens with so much astonishment after a person passes away. The following three inscriptions represent three different approaches of an ancient man. Each of these inscriptions reflects the location in which it was formulated.

The deceased Roman woman $\left(2^{\text {nd }} / 3^{\text {rd }}\right.$ cent. $)$ had facial features and figure of Aphrodite and an extraordinary soul. Marcia Helike obeyed the Commandments

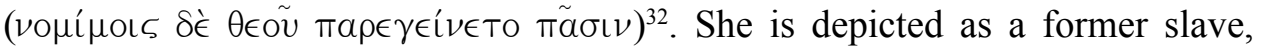
honest in her actions, a loving wife and a mother of three. This particular inscription reflects a mix of Judeo-Christian and pagan thinking. Marcia's beauty in her lifetime equalled that of the goddess of love and her post mortal beauty equalled that of Penthesileia, a queen of the Amazons ${ }^{33}$. In her actions, she was inspired by moral commands of a monotheistic religion.

Despite all of the admirable traits she possessed, she remains in her grave. Her loving husband made sure that she would be remembered by the passersby and

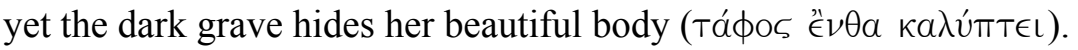

The following tombstone inscription reveals some shift in thinking towards divinization of the departed. It depicts a life and beauty of Tryphera, a wife of Hermeros from Athens $\left(3^{\text {rd }} / 4^{\text {th }} \text { cent. }\right)^{34}$. The inscription stresses especially her outer beauty; the deceased had beautiful complexion, hair, eyes, mouth, lips, teeth, and voice. What's more, she attained other virtues too ( $\lambda \lambda \epsilon^{\prime} i \quad \sigma \omega ́ \mu \alpha \tau \iota$ $\left.\theta \tilde{\epsilon} \sigma \alpha\right)$ : she was a loving wife and a mother of a lovely child.

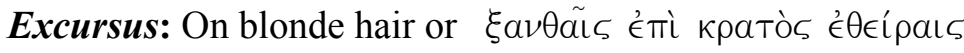

Greek mythology tells us that exceptionally beautiful women were admired not only by mortal men, but also by the Olympian deities. That naturally aroused jealousy among their heavenly female companions. The interest of gods in mortal women was not just a theoretical affair immortalized in odes. The pursuit and se-

31 Kaibel $n^{\circ} 174$; see a detailed list of inscriptions praising the beauty of the deceased and the purity of their bodies in pp. A. Wypustek, Images of Eternal Beauty in Funerary Verse Inscriptions of the Hellenistic and Greco-Roman Periods (Leiden - Boston: Brill 2013) 188.

$32 \mathrm{GG} \mathrm{n}^{\circ} 392=\mathrm{GV} \mathrm{n}^{\circ}$ 1164; Kaibel n 727; IG XIV n 1839.

$33 \quad \mathrm{GG} \mathrm{n}^{\circ} 317=\mathrm{GV} \mathrm{n}^{\circ} 1163$.

$34 \mathrm{GG} \mathrm{n}^{\circ} 293=\mathrm{GV} \mathrm{n}^{\circ}$ 746; Kaibel n 169; IG II/III'², III, 2, nº 12828. 
duction of women often resulted in an intermingling of the earthly and the divine. The implications of such action differed. In the best scenario, the women ended up in Mount Olympus. It a worse scenario, they sought to liberate themselves from sorrow and misery through metamorphosis into plants or animals. In the worst-case scenario, the situation ended in tragedy.

Nevertheless, this story occurs repeatedly across the generations: every woman desires the looks of Aphrodite. The tombstone inscriptions referring to the goddess of love demonstrate just that. Women yearn to be admired and fulfil their reproductive role. Men want to conquer and leave their mark on history. Blonde hair is a feature of exceptional beauty; women with blonde hair are considered feminine and innocent. In men, blonde women arouse desire that blinds good judgement.

For Homer, the first women of this type were the golden goddess Aphrodite $(I l .4,14 ; 9,389)$ and luminous Helen of Troy $(I l .3,121)^{35}$. There are other attributes of beauty that we can find in Homer's writings: lily-white arms (Il. 5,314), perfect neck, tempting breasts and sparkling eyes (Il. 3,396, cf. Colluthus, Rapt. Hel. 82ff). Similar beauty parameters are included in the inscription from Athens $\left(3^{\text {rd }} / 4^{\text {th }}\right.$ cent. $)$ which praises impeccable female beauty ${ }^{36}$.

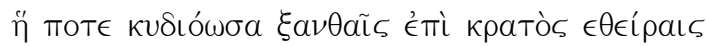

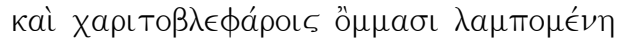

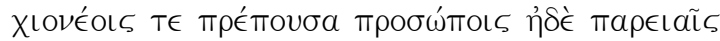

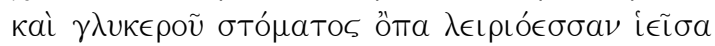

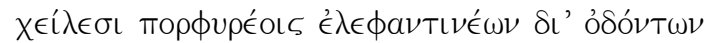

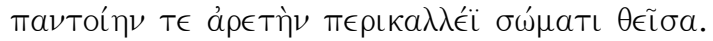

1 Die einst auf ihrem Haupt die Pracht blonder Locke trug,

die aus Augen blickte, deren Sterne Anmut strahlen,

3 deren Antlitz und Wagen schimmerten wie Schnee,

deren süssem Mund die lieblichste Stimme entströmte,

5 über Purpurlippen durch Zähne blendend wie Elfenbein,

die welche zu ihres Leibes Schönheit jegliche Tugend fügte, die Frau,

(German translation: W. Peek)

35 For Homer, blonde hair and blue eyes were symbols of beauty. Other goddesses and heroes had the same hair colour: Demeter (Il. 5,500), Agamede (Il. 11,740), Achilles (Il. 1,197; 23,141), Menelaos (Il. 4,147), Odysseus (Od. 13,399.431); and On the other hand, Poseidon, god of the sea had dark hair and dark eyes (Od. 3,6). Other writers of antiquity idealised blonde hair too: Ariadne (Hesiod, Theog. 947), Helen (Sappho, Supp. 13,5), Harmonia (Euripides, Medea 834), Athena and Graces (Pindar, Nem. 10; according to Homer, Athena had blue eyes too $(I l .1,206)$. For more details see H. G. Liddell - R. Scott, Greek-English Lexicon (New York: Harper \& Brothers 1897) 1016. The Bible also mentions men who would sprinkle their hair with gold dust to make their head sparkle in the sun. Flavius Josephus mentions the same about the horsemen of the king Solomon (Antiq. 8:7.3);A. Novotný, Biblický slovník (Praha: Kalich 1956) 1216. $\mathrm{GG}^{\circ} 293=\mathrm{GV}$ n $^{\circ}$ 746; Kaibel ${ }^{\circ} 169$, IG II/III ${ }^{2}$, III, 2, $\mathrm{n}^{\circ} 12828$. 
The most recent study of women in antiquity, particularly in the subchapter dedicated to women in Cyprus - the place of birth and worship of Aphrodite (Hesiod, Theog. 190-197) identifies motherhood and reproduction as important roles of a woman ${ }^{37}$. This was also captured on female sculptures that were found at the archaeological excavation site in Cyprus. The sculptures accentuate certain parts of a female body (e.g. a long neck adorned with jewels, earrings on ears, lips, eyes, large breasts, wide hips) extolled by ancient writers and authors of tombstone inscriptions, like the one from Athens.

They referred to the influence of the goddess of love, beauty, sexuality, and fertility as one of the most powerful Olympians. She had influence not only over mortals but gods as well and demanded respect and appreciation. Severe punishment awaited anyone who refused. Whoever observed and presented at least one of her characteristic traits could contemplate their own divinization.

Areskusa (Boiai, Lakonien. $2^{\text {nd }} / 3^{\text {rd }}$ cent.?) went through the process of divinization and was praised for the life she had lived. ${ }^{38}$ Although she died unmarried, unlike other women, she was a gem $(\ddot{\alpha} \gamma \alpha \lambda \mu \alpha)$ treasured by her family. She devoted her whole life to serve the gods and became a guardian of the temple.

She excelled in outer beauty and inner qualities. Virtues, wisdom and beauty granted her immortality. The gods took her to Mount Olympus ${ }^{39}$, where she sat as

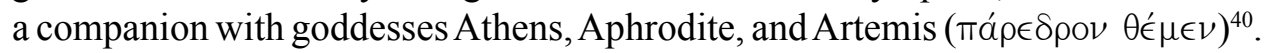

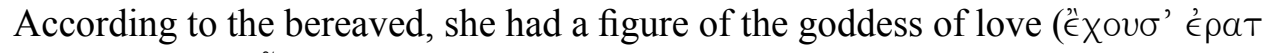

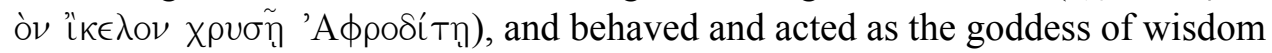

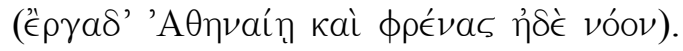

The abovementioned inscriptions create an impression that all deceased women were great beauties and flourished into absolute perfection in their virtuous lives. As if many of them could fill the pages of some beauty catalogue and ordinary women, troubled by different external factors simply did not exist.

Wypustek claims that idealization of female beauty, attractiveness, and virtues is one way of coping with the loss of the beloved person. Evoking the beauty of a young person helps soothing pain and despair, even if the person died old $^{41}$. Therefore, tombstone inscriptions, reliefs or sculptures console the relatives and casual readers by evoking the beauty of the deceased, which is immortalized in places where death has no destructive impact.

L. Budin - J. M. Turfa (ed.), Women in Antiquity: Real Women across the Ancient World (Rewriting Antiquity; New York: Routledge 2016) 343-434.

$\mathrm{GG} \mathrm{n}^{\circ} 318=\mathrm{GV} \mathrm{n}^{\circ}$ 924; IG V, $1 \mathrm{n}^{\circ} 960$.

As Greek tombstone inscriptions reveal that Areskusa counts among the smaller group of women taken to Mount Olympus after they have passed away

Even smaller percentage of women sat at the judge's chair beside Olympian gods.

Find a detailed list in Wypustek, Images of Eternal Beauty, 185-196. 


\subsection{A brief summary of presented ideas}

The abovementioned tombstone inscriptions approach the concept of beauty in many different ways.

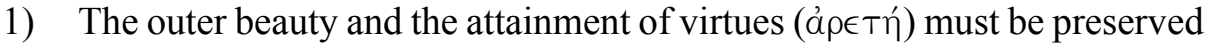
in the memory of future generations.

2) Virtues shaped by life experiences and attitudes flourish at the advanced age.

3) Outer beauty diminishes with age.

4) On the other hand, young means beautiful.

5) What needs to preserved is a young human body full of life and strength and with no signs of aging. ${ }^{42}$.

6) One of the most important reasons is being closer to the gods and maintaining immortality. Who dwells on Mount Olympus remains young and beautiful.

7) Youth and beauty are important attributes that reflect the concept of imitation of the gods in human lives.

\section{Greek and Early Christian inscriptions. Differences and similarities}

It is rather interesting to observe Greek and Early Christian inscriptions. While some themes are identical, others are rather different. It is not always easy to clearly distinguish between a pagan and a Christian gravestone inscription. The interactions between the two worlds were intense. Both worlds complemented and enriched one another. Christian tombstone inscriptions, however, indicate some divergence from pagan ideas.

Reading the inscriptions, we are yet again confronted with the difficulty of generalization of a thesis into a universally valid claim. This concerns mainly Greek tombstone inscriptions. It is a proof of just how rich was the Greek world of thought.

The following inscription from Alexandria is Christian in its nature. According to the Egyptian calendar, it dates back to Phamenoth 23, the rule of consuls Bass and Philip, which correspondents to 19 March $409^{43}$.

42 Find a detailed list in Wypustek, Images of Eternal Beauty, 185-196.

43 G. Lefebure, Recueil des inscriptions grecques-chrétiennes d'Egypte (Kairo: Imprimerie de 1'Iinstitut Français d'Archéologie Orientale 1907) n 49, taken from C. M. Kaufmann, Handbuch der altchristlichen Epigraphik (Freiburg im Breisgau: Herdersche Verlagshandlung 1917) 145. 


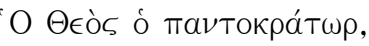

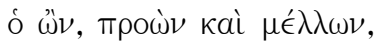

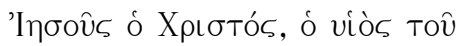

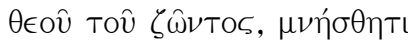

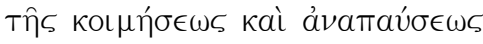

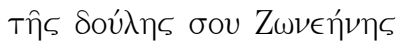

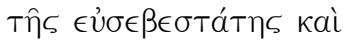

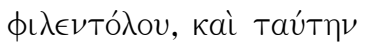

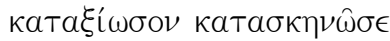

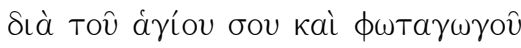

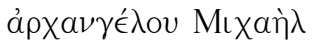

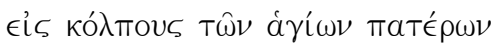

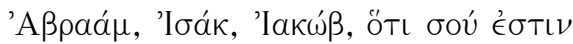

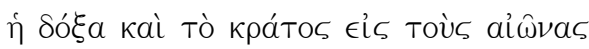

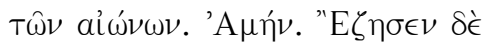

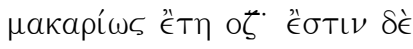

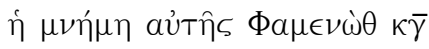

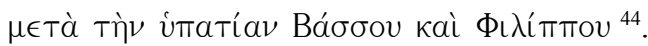

Der Gott, der Allmächtige,

der Seiende, der Gewesene, der Zukünftige,

Jesus Christus, der Sohn des lebendigen Gottes, erinnere

dich der Ruhestatt und des Hingages

deiner Dienerin Zoneine

der sehr frommen

und gehorsamen,

und gestatte, dass diese gewürdigt werde,

aufgenommen zu werden durch deinen heiligen,

zum Lichte führenden Erzengel Michael

in Scholz der heiligen Väter Abraham, Isaak und Jakob,

den dein der Ruhm und die Kraft von Ewigkeit

zu Ewigkeit. Amen. Sie lebte glücklich 77 Jahre;

es ist aber ihr Gedächtnis am 23. des Phamenoth

nach dem Konsulate des Bassus und Philippus.

(German translation: C. M. Kaufmann)

This inscription from Alexandria is interesting for several reasons. Firstly, it deviates from the pagan ideas associated with the female beauty. There is no exaltation of a woman's physical appearance. In comparison to the inscription

44 Kaufmann, Handbuch, 145. 
from $2^{\text {nd }} / 3^{\text {rd }}$ century Egypt mentioned above, there is a considerate shift in thinking ${ }^{45}$. A Christian woman does not have the desire resemble some of the female deities, preserve her body for as long as possible, and thus secure her place on Mount Olympus. Just the contrary. The inscription clearly reads that the deceased Zoneine died at the age of 77 . We can hardly speak of wrinkle-free skin and thick hair in this advanced age.

Surely, some Greek tombstone inscriptions reveal the age of the deceased women $^{46}$. This illustrates the prevalence of Judeo-Christian perception of age the older the person, the greater blessing from $\operatorname{God}^{47}$. Besides that, the number seven is a number of fullness.

The early Christian tombstone inscriptions share certain similarities with the Greek ones, for instance a list of virtues in which the deceased person excelled

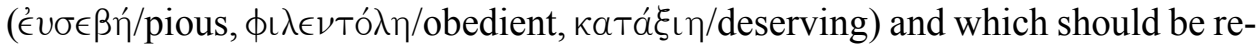
membered.

Greek tombstone inscriptions count upon collective memory ${ }^{48}$ and express hope that the gods will not forget the deceased person and that his or her human life will be praised. The Christian inscription from Egypt expresses reliance on Lord's memory (cf. Psalm 8:5; 25:7). It refers to God's attributes such as omnipotence, existence, life, future, and eternal power. All of these are greatly important for a person living in hope. The inscription reveals that the deceased was a servant of God ( relate to the earnest expectation or a reward for the deceased's attitudes during his or her lifetime.

Another similarity is related to a final resting place ${ }^{49}$. The inscription reveals that the deceased was laid to rest in the bosom of Abraham, Isaac and Jacob, carried there by the archangel Michael, the bearer of light. The earliest mention of such a place is found in the prayer for the departed from Nubia that dates back to $344^{50}$. The bosom of the forefathers is portrayed as a place of rejuvenation freed

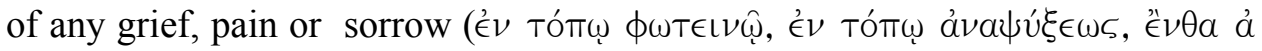

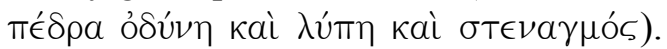

Every tombstone inscription reminds us of the inevitable reality of death. This particular Christian inscription tells us that death is not the end because the de-

$45 \mathrm{GG} \mathrm{n}^{\circ} 263=\mathrm{GV} \mathrm{n}^{\circ}$ 1411; Milne, Greek Inscriptions.

46 Cf. A. Korečková, „Príčiny úmrtia antických žien”, TF 2 (2014) 39-51.

47 "The fear of the Lord prolongs life, but the years of the wicked will be short." (Proverbs 10:27), see also Psalm 90:10.

48 For instance, the tombstone inscription from Philomelion, Phrygien $\left(1^{\text {st }}\right.$ cent. $\left.\mathrm{BC}\right)$ reveals the deceased wishing a pilgrim a better life than she had. The cruel ordinance of the Fates forced her to abandon her three children. In addition, they who disrespect her memory is doomed to the same fate: illness, pain and death. GG n ${ }^{\circ} 431=\mathrm{GV} \mathrm{n}^{\circ} 1870$; Kaibel ${ }^{\circ} 248$.

49 For an indepth look at this issue see I. Peres, Griechische Grabinschriften, 69-121.

50 Kaufmann, Handbuch, 146-147. 
ceased relies on God. She puts her trust in God just as she did in her earthly life described here as $\mu a k a \rho i ́ \omega s$ (supremely blessed, happy, blissful ${ }^{51}$ ) and thus she can rest in peace ${ }^{52}$.

\section{Early Christian literature or true female beauty}

Early Church fathers' writings emphasize building spiritual relationship with God and avoiding any disruptive elements. Wealth, beauty, grooming, inappropriate behaviour, etc. represent the temptations hindering our spiritual advancement.

Church fathers encourage the faithful to seek true moderation. Any extreme adornment of our body means denying our faith in Jesus Christ. What is expressed as the attainment of virtues and emulation of the divine style in Greek tombstone inscriptions is paradoxically perceived as straying from the path of true faith.

For instance, Church Father Cyprian wrote: “...Or does she groan and lament who has time to put on the clothing of precious apparel, and not to consider the robe of Christ which she has lost; to receive valuable ornaments and richly wrought necklaces, and not to bewail the loss of divine and heavenly ornament? Although you clothe yourself in foreign garments and silken robes you are naked; although you adorn yourself with gold, pearls and gems yet without the adornment of Christ you are unsightly. And you who stain your hair, now at least cease in the midst of sorrows; and you who paint the edges of your eyes with a line drawn around them of black powder, now at least wash your eyes with tears..." (On the lapsed 30) ${ }^{53}$.

"The work of God and His fashioning and formation ought in no manner to be adulterated, wither with application of yellow colour, or with black dust or rouge, or with any kind of medicament which can corrupt the native lineaments" (On the dress of Virgins 15) ${ }^{54}$.

\section{Conclusion}

Purity shines and sanctifies. Heavenliness calls for perfection. Beauty evokes pleasure. All of these themes are in one way or another embedded in tombstone inscriptions. Perfection is associated with the Olympian deities. Beauty in this

51 Panczová, Grécko-slovenský slovnik, 788.

52 ore on Christian tombstone inscription see A. Korečková, Žena a smrt' [Woman and Death] (Habilitation thesis; before completion).

53 Detailed explanation with translation in Panczová, Grécko-slovenský slovnik, 10.

54 Translated by H. Panczová, O nepravej ženskej kráse (Bratislava: Dobrá kniha 2007) 11. 
respect is then associated with good things or virtues. The gods would not portray themselves as unsightly after all.

What is ugly or tainted is associated with the underworld. Humans suffer in the company of Hades. For that reason, they strive to be in the company of gods. It is only understandable that people wanted to secure a better future, or even their own divinization through the imitation of the gorgeous Olympians.

Imitation in some way is also found in the New Testament ${ }^{55}$. Apostle Paul repeatedly admonishes the readers of his letters to imitate him (1 Cor 4:16, 11:1) and those who lead an exemplary life in Christ (Phil 3:17; 1 Thess 1:6; 2 Thess $3: 7-9 ; 1$ Thess $2: 14)$. He praises those who follow his advice and hold them up as an example for other people.

The imitation of Paul is indeed a true understanding of what it means to follow Christ through His cross and suffering ${ }^{56}$. In the Letter to the Ephesians, Paul admonishes believers to follow God's example (5:1). Believers should follow Christ and be kind, compassionate, and forgiving to one another (4:32, 5:2).

Attitudes towards female beauty praised in Greek tombstone inscriptions change. What was once seen as virtue becomes forbiddance; adornments and clothing become sinful. Modest clothing, good deeds, full submission to a man, prohibition to teach in public, childbearing, living in quietness and humility $(1 \mathrm{Tm} 2: 9,10)$ were the attributes that needed to be praised. This is the path designed for a woman following Christ. This radical shift is perhaps a reaction to cult worship of the goddess of love, beauty, and sexuality, which was associated with cult prostitution. Accentuation of female features had to be stamped out because it was seen as a source of temptation or a failure of society.

\section{Bibliography}

Arnold, D., The Royal Women of Amarna: Images of Beauty from Ancient Egypt (New York, NY:

Metropolitan Museum of Art 1996).

Bahník, V., Slovník antické kultury (Praha: Nakladatelství Svoboda 1974).

Breemer, D. (ed.), Pindar. Siegeslieder (München 1992).

Budin, L. - Turfa, J. M. (ed.), Women in Antiquity: Real Women across the Ancient World (Rewriting

Antiquity; New York, NY: Routledge 2016).

Charlesworth, J. H., The Old Testament Pseudepigrapha: Apocalyptic Literature and Testaments (1.

vol., New Haven, Connecticut: Yale University Press 1983).

Geffcken, J., Stimmen der Griechen am Grabe (Hamburg - Leipzig: L. Voss 1893) [= Geffcken].

Green, L., „Beauty”, The Oxford Encyclopedia of Ancient Egypt (ed. D. B. Redford) (Oxford: Oxford

University Press 2001) I, 167-170.

55 M. J. Wilkins, „Imitate, Imitators”, AYBD III, 392.

56 B. Sanders, ,Imitating Paul: 1 Cor 4:16”, HTR 74 (1981) 363. 
Jalabert, L. - Mouterde, R. (ed.), Inscriptions grecques et latines de la Syrie, III,1. Région de l'Amanus. Antioche (Paris: Paul Geuthner 1950) [= IGLSyr]

Jalabert, L. - Mouterde, R. (ed.), Inscriptions grecques et latines de la Syrie, III, 2. Antiochène (Paris: Paul Geuthner 1950) [= IGLSyr]

Kaibel, G., Epigrammata Graeca ex lapidibus conlecta (Berlin: Reimer 1878). (= Kaibel) [=Kaibel].

Kaibel, G. (ed.),. Inscriptiones Italiae et Siciliae additis Graecis Galliae, Hispaniae, Britanniae, Germaniae inscriptionibus (Inscriptiones Graecae XIV; Berlin: Reimer 1890) [= IG XIV].

Kaufmann, C. M., Handbuch der altchristlichen Epigraphik (Freiburg im Breisgau: Herdersche Verlagshandlung 1917).

Kirchner, J. (ed.), Inscriptiones Atticae Euclidis anno posteriores, Part III, Fasc. 2, Tituli sepulcrales (Inscriptiones Graece II/III' ${ }^{2}$ Chicago, IL: Ares 1974) [= IG II/III' ${ }^{2}$ III, 2].

Kolbe, W. (ed.), Inscriptiones Laconiae Messeniae Arcadiae, Fasc. 1, Inscriptiones Laconiae et Messeniae (Inscriptiones Graecae V; Berlin: Reimer 1913) [= IG V, 1].

Korečková, A., „Príčiny úmrtia antických žien”, Testimonium Fidei 2 (2014) 39-51.

Korečková, A., Žena a smrt' [Woman and Death] (Habilitation thesis; before completion).

Lefebure, G., Recueil des inscriptions grecques-chrétiennes d'Egypte (Kairo: Imprimerie de l'Iinstitut Français d'Archéologie Orientale 1907).

Liddell, H. G. - Scott, R., Greek-English Lexicon (New York, NY: Harper \& Brothers 1897).

Mayordomo, M., „Möglichkeiten und Grenzen einer neutestamentlich orientierten Tugendethik”, Theologische Zeitschrift 64 (2008) 213-257.

McDonald, M. F., Lactantius. The Divine Institutes. Books I-VII (Washington, D.C.: Catholic University of America Press 1964).

Milne, J. G., Greek Inscriptions (Oxford: Printed at the University Press by Horace Hart 1905).

Novotný, A., Biblický slovník (Praha: Kalich 1956).

Panczová, H., Grécko-slovenský slovnik od Homéra po krest’anských autorov (Bratislava: Lingea 2012).

Panczová, H., O nepravej ženskej kráse (Bratislava: Dobrá kniha 2007).

Peek, W., Griechische Grabgedichte (Schriften und Quellen der Alten Welt 2; Berlin: Akademie-Verlag 1960) [= GG]

Peek, W., Griechische Vers-Inschriften I: Grab-Epigramme (Berlin: Akademie Verlag 1955) [= GV].

Peres, I., Griechische Grabinschriften und neutestamentliche Eschatologie (Wissenschaftliche Untersuchungen zum Neuen Testament 157; Tübingen: Mohr Siebeck 2003).

Rupé, H. (ed.), Homer, Ilias (München 1989)

Voight, E.-M. (ed.), Sappho und Alcaeus. Fragmenta (Amsterdam: 1971).

Sanders, B., „Imitating Paul: 1 Cor 4:16”, Harward Theological Review 74 (1981) 363.

Schirnding, A. (ed.), Hesiod. Theogonie. Werke und Tage, griechisch und deutsch (München 1991).

Schönberger, O., Kolluthos, Raub der Helena. Griechisch-Deutsch (Würzburg: Konigshausen \& Neumann 1993).

Seeck, G. A. (ed.), Euripides (6. vol., München: 1972-81).

Svoboda, L., Encyklopedie antiky (Praha: Academia 1973).

Thackeray, H. (ed.), Josephus (10 vol., London: 1926-1965).

Vernant, J. P. (ed.), Řecký člověk a jeho svět (Praha: Vyšehrad 2005).

Weiher, A. (ed.), Homer, Odyssee Griechisch und Deutsch (München: Heimeran 1990). 
Wilkins, M. J., „Imitate, Imitators”, The Anchor Yale Bible Dictionary (ed. D. N. Freedman) (New York: Doubleday 1996) III, 392.

Wypustek, A., Images of Eternal Beauty in Funerary Verse Inscriptions of the Hellenistic and GrecoRoman Periods (Leiden - Boston: Brill 2013).

Zamarovský, V., Bohovia a hrdinovia antických bájí (Bratislava: Perfekt 1998). 
